\title{
IDENTITY AND SELF-PRESENTATION IN LETTERS OF REQUEST WRITTEN BY COLLEGE STUDENTS
}

\author{
Maria Corazon Saturnina A. Castro \\ University of the Philippines-Diliman \\ mcsacastro@gmail.com \\ DOI: https://doi.org/10.24071/ijhs.2018.020102 \\ received 26 June 2018; revised 12 August 2018; accepted 14 August 2018
}

\begin{abstract}
Participants in an interaction risk their sense of face in every action (Goffman, 1967). Requests, by definition, are face-threatening acts (Brown and Levinson, 1978). In making a request, a speaker not only threatens the hearer's negative face as he impinges on the hearer's claim to freedom of action; he also threatens his positive face as he exposes himself to the possibility of being denied or rejected. In order to minimize this possibility, the speaker has to present himself in such a way that the hearer would have a positive impression of him. This paper examined letters of request written by students of a university in Metro Manila for noticeable forms of self-presentation. Following Goffman's thesis (1956) that self-presentation is a tangible component of identity, this paper analyzed lexicosyntactic patterns, and impression management strategies utilized by the writers to express their communicative intention (make a request), and construct an identity deemed necessary in attaining the hearer's approval.
\end{abstract}

Keywords: face, request, self-presentation, impression management, identity

\section{Introduction}

Participants in an interaction risk their sense of face in every action (Goffman, 1967). A request, by definition, is a face-threatening act (Brown and Levinson, 1978). It is a directive act performed to get the hearer to do something that is to the speaker's benefit and at the cost of the hearer. From the speaker's point of view, the hearer is able to do this act but it is not obvious that the hearer will do it in the normal course of events or of the hearer's own accord (Searle 1969). In making a request, a speaker not only threatens the hearer's negative face as he impinges on the hearer's claim to freedom of action; he also threatens his positive face as he exposes himself to the possibility of being denied or rejected. In making a request, one must create an emotional atmosphere that will ensure the addressee's positive response; therefore, the use of appropriate tone, organizational as well as politeness and persuasive strategies are paramount in order for him to create a positive impression to elicit the preferred response from the addressee. In other words, effort is exerted to convey a positive selfpresentation. 
Requests have been one of the most researched areas in cross-cultural, intercultural, and interlanguage pragmatics (e.g. Blum-Kulka \& Oshtain, 1984; Byon, 2006; Baron, 2008, Shively, 2011). Most of these studies, however, highlight the relationship between politeness and requests (e.g. Hassall, 1999 \& 2003; Rue \& Zhang, 2008; Ogiermann, 2009). This study hopes to contribute to the body of knowledge on requests by examining not only politeness but also other linguistic and discourse phenomena particularly identity construction and self-presentation that relate to successful request making in a specific discourse community.

\section{Statement of the Problem}

This paper examined letters of request written by students of a university located in Metro Manila for noticeable forms of self-presentation. Following Goffman's thesis (1956) that self-presentation is a tangible component of identity, this paper analysed lexico-syntactic patterns, and impression management strategies utilized by the student writers to express their communicative intention (make a request), and construct an identity deemed necessary in attaining the hearer's approval.

This paper poses the major question: What identities are constructed by the varying types of self-presentation manifested in letters of request? This major query is broken down into the following sub-questions:

1. How do the writers of the letters of request present their requests in terms of form and organization?

2. What linguistic and impression strategies are utilized by the writers to show positive values that are deemed acceptable by their addressees?

3. How does the interrelationship between the form and organization of the letters and the language used by the writers create a positive selfpresentation by the writers?

\section{Conceptual Framework}

This paper is anchored in the works on the Face and Self-Presentation of Erving Goffman; the Politeness Theory of Brown and Levinson; and the SelfPresentation Strategies of Jones and Pittman (1982) and Scott and Lyman (1968).

According to Goffman (1957), participants risk their sense of face in every interaction. Goffman describes a person's face as an image of self that is based on social expectations. It addresses the questions, "Who am I supposed to be in this situation? What behaviors are expected of me? To maintain one's face, particular behaviors must be enacted and not others. Goffman described several types of face-work that people engage in to protect their face and that of others. These are rituals - doing routine behaviors that are considered polite and are expected to be enacted by participants in their everyday encounter; corrective process correcting a negative act done on another person by means of an apology; avoidanceavoiding a person who is deemed to be a threat; and poise-controlling embarrassment when one's face is threatened by exhibiting poise.

Brown and Levinson (1978) expanded the concept of face by defining it as that which all interactants are assumed to have an interest in maintaining during interaction where 'positive face' is the positive and consistent image people have of themselves and their desire for approval; on the other hand, 'negative face' is the basic claim to territories, personal preserves, and right to non-distraction. 
When the face is threatened, a speaker may choose from a variety of politeness strategies to avoid or minimize damage to the face.

Closely related to Goffman's notion of the face as the image that is based on social expectation is his concept of self-presentation (1956). To Goffman, social interaction is like a stage and the people who engage in interactions are actors who perform a variety of roles. He used the term 'performance' to mean the activity of an individual in front of others. Through this performance, he delivers impressions to others and information is conveyed to create an identity which the audience attributes to the individual but which the individual may or may not be aware of. Important concepts in Goffman's self-presentation include setting; appearance; manner; front; and front, back, and off stage. Setting refers to the location where the interaction takes place. Since different settings have different types of audience/interactants, an individual/actor has to change performance appropriate to the setting. The appearance has to do with the performer's social status as reflected in his occupation, gender, age, etc. Manner refers to how an individual performs his role; it also tells the audience how the individual will act out his role. For example, a professor is supposed to behave in a respectable manner and must not talk in a vulgar manner. If the professor behaved otherwise, his appearance and manner are inconsistent and may confuse his interlocutor. The front is the image /impression an individual conveys to the audience. Often, he follows a social script on how to behave or interact in an interaction. Everyday interactions have three stages - the front where the individual has to perform because he is constantly watched; the back where the individual can be himself; and off stage where the individual may meet his audience outside the front stage. To illustrate, a student performs and behaves in front of his professor; be himself in his own room; and meets and talks in a quite relaxed way to his professor outside the classroom. Goffman's thesis is that the presentation of self is the intentional and tangible component of identity. An individual/actor engages in intra-self negotiations to project a positive impression which Goffman called impression management.

The number of impressions that people construct of themselves in the mind of others is varied and limitless. Jones and Pittman (1982) created a taxonomy that includes five common self-presentational strategies - ingratiation; self-promotion, intimidation, exemplification, supplication. The objective of ingratiation is to make other people like an individual through that individual's imitation, flattery, doing favors for others, or displaying positive personal characteristics (Jones, 1990). In self-promotion, the individual tries to convince his audience of his ability, competence, intelligence. Intimidation is the strategy used by the individual who wants to be feared; be viewed as powerful or ruthless. By using exemplification, one may construct an impression of being morally upright, righteous. Finally, supplication occurs when an individual publicly admits weaknesses and deficiencies.

Other researchers expanded the taxonomy by adding other strategies. Scott and Lyman (1968) presented an analysis of one kind of talk called the account. An account 'is a linguistic device employed whenever an action is subjected to valuative inquiry.' There are two types of accounts - excuses and justifications. Excuses are accounts in which an individual admits that the act in question is bad, wrong, or inappropriate but denies full responsibility. Justifications, on the other 
hand, are accounts in which one takes full responsibility for the act in question. To justify an act is to assert its positive value in the face of a contrary claim. Accounts are given in a variety of ways. The linguistic form of the account is expected to be socially suited to the norms of culture and situation. The acceptance of refusal of an account depends greatly on the appropriateness of the language used. Failure to employ linguistic style may result in dishonoring the account.

All of these frameworks contribute to the understanding of writing a letter request as process whereby participants (writer and reader) negotiate identities the writer creates a positive identity through appropriate self-presentation (using various linguistic and organizational strategies) so his request would not be denied; that way, he is able to maintain his face. The reader/addressee infers from the form and linguistic style of the letter an identity of the writer that would significantly influence his decision to approve or deny the request.

\section{Method}

One hundred letters of request processed by the Office of the College Secretary of the College of Arts and Letters of the university were randomly selected and permission was requested via online (email). Except for one, all the students gave their consent for their letters to be part of the study. The data were initially classified in terms of structure and organizational following Reep (2003). Afterwards, the presentation strategies were evaluated and categorized based on the self-presentation strategies presented by Jones and Pittman (1982) and Scott and Lyman (1968).

\section{Findings and Discussion}

In writing a letter of request, the writer may use the direct or indirect organization (Reep, 2003). The direct organization has generally three sections:

1. The opening which establishes the reason for writing and presents the main idea-statement of the request;

2. The middle part which explains details about the situation;

3. The closing which reminds the reader of the call for action or looks to future interaction between the writer and the reader.

The indirect organization, on the other hand, has:

1. A "buffer" part before the request. It is usually an introduction of oneself. The introduction gives the reader an idea of who the writer is and his predicament.

2. The statement of the request

3. Details of the request

4. Expression of thanks

An evaluation of the organization of the letters revealed that $75 \%$ used the indirect organization. The preponderance of the indirect organization is consistent with the Filipinos' dislike for directness and confrontation. According to Filipino anthropologist Jocano (2001), the Filipino communication style involves pahiwatig (hint or suggestion); pabatid (to make conscious); and finally pahayag 
(to reveal). It is considered rude to be direct and so one has" to go around the bush" before stating the request. It is considered good behavior (magandang asal) to minimize directness. Often, good behavior is a standard against which the personhood of the writer is known and expressed. To be perceived, therefore, as having good behavior is paramount in achieving the desired response from the reader.

For Goffman, by choosing indirectness which is actually a negative politeness strategy, the speaker (the writer of the request letter) recognizes the social distance between him and his audience (reader). This recognition is brought about by the respect he has for his reader. This distance is reflected in language by the use of hedges, and apologies prior to the statement of request.

Several research have studied the correspondences between politeness and other phenomena related to requests (e.g. Brown \& Levinson, 1978; Roloff and Barnicott, 1978; Cody, Woelfel \& Jordan, 1983). The conclusion of these studies is that the speaker's indirectness which is synonymous with politeness varies according to the speaker's relationship with the hearer, and according to the nature of what is being requested, along with the potential benefits of complying with the request (Bilbow, 1995). What is the link, therefore, between politeness, indirectness, and request? According to Hendricks (2002), the link with politeness is that indirectness is one type of strategy that speakers can resort to in their attempt to protect a hearer's face when making a request. As such, politeness will be interpreted as the prime motivator for the use of indirectness.

Of the letters which used indirect organization, $80 \%$ started with selfintroduction. The students stated their names, courses, year levels, and in some cases their student numbers. The self-introduction was the students' way of initially providing a context for their letters. For instance, when a student identifies himself/herself as a 'graduating' student, the communication dynamics can change into one that would have an added amount of consideration for the student. In this particular university, graduating students are given some preference - that is to say, they have a special day for registration; they are allowed to enlist in a class even if the class is already filled up; and they are usually given residency extensions. However, in many instances, the selfintroduction in the letters fundamentally fulfilled a socially acceptable and conventional act of politeness on the part of the students.

Ten percent $(10 \%)$ of the letters started with a greeting-Good day. As young children, we have been trained to greet people and make polite conversations. Whenever we enter somebody else's house or office, we say hi or good morning. This kind of politeness extends to the written discourse. For some students, stating the request without greeting first may be interpreted as being rude and impatient. The greeting is a strategy to give deference to the reader to make him feel respected and appreciated. More than being phatic, greetings are expressions of politeness and are reflective of one's being 'cultured' and 'educated.'

Another $10 \%$ of the letters started with expressions of apology and regret. In these letters, the students highlighted their weaknesses (internal as in depression, sickness or external as in family problems) that led to their inability to comply with the university policies/rules. 
Examples: 1. " On account of my balance due to unsettled student loan last semester, I am in deepest regret to inform your office that I will not be able to comply with such deficiency. I was diagnosed with posterior wall hyperthrophy and pulmonic regurgitation."

2. "I apologize for not being able to comply with the deadline of payment due to my mother being unable to leave the house in order to withdraw the necessary amount in time. She has been ill and only recently recovered."

The attention given to the apology prior to the statement of request arouses a sense of sympathy and to some extent, moral and social obligation. When a student writes about personal crises all occurring at the same time, the reader is moved emotionally and more often than not, the request is approved for 'humanitarian reasons.'

In summary, the indirect organization reflects two significant impression management strategies-1. To show politeness and good breeding; 2. To emotionally move the reader before the revelation of the request.

The letters that show direct organization comprise $25 \%$ of the letters and are broken down as follows:

1. Request for late payment $(40 \%)$

2. Request for residency extension (20\%)

3. Request for change of matriculation $(6 \%)$

4. Request for readmission to the program (17\%)

5. Request for readmission from AWOL (17\%)

The requests for late payment were noticeably short. The first paragraph had 3-5 sentences and the first sentence stated the appeal or the request and the remaining sentences accounted for the reason/s for the request. In most letters, the reasons ranged from the family's financial difficulties, delay in remittances from OFW (Overseas Filipino Workers) family members. $16 \%$ of the students were working students who also appealed for consideration for their delayed salaries. What is noticeable, however, is that the last sentence assured the university of the intention of the students to pay on specific dates. The commissive act was explicitly stated by the performative "I promise to pay" or by the modals in, "I will pay"; "I shall complete payment." The commitment shown in the letters reflected the students' maturity in acknowledging that the privilege to continue studying in the university comes with a responsibility.

The other letters were longer due to the nature of the request. The requests for extension of residency had mostly family circumstances as primary reasons the student had to take on odd jobs to help the family; the student had to work in the family business to make ends meet; the student had to take care of ailing family members, etc. The reader could get the impression of a family-oriented person who had to temporarily forego his studies to help the family but, at the moment, ready to go back to school. In requests for readmission, the students admitted their inadequacies and delinquency. 
Ex 3: "I failed Bio 1 because I lacked focus, self-management, and discipline. I am sure that I can do better next time and will continue to be diligent in my studies."

"I admit that I have failed to deliver the right and sufficient performance that is needed to pass the subject... I understand now my weaknesses..."

The courage to admit one's inadequacies created an impression of honesty and sincerity on the part of the students. Though sometimes bordering on the fallacy of ad misericordiam, the appeals nonetheless, impressed upon the reader an overwhelming pathos in favor of the students.

In the next discussion, we look at the self-presentation strategies utilized by students to show positive values deemed acceptable by the reader.

A non-parametric statistical analysis of the self-presentation strategies found in the data yielded the following results:

1. Sixty-six percent (66\%) of the student writers used a combination of at least two self-presentation strategies. In decreasing order, the self-presentation strategies are 1) Supplication and Exemplification; 2) Justification and Exemplication 3) Excuse and Exemplication; 4) Apology and Justification; 5) Justification and Self-promotion.

2. Only thirty-four percent (34\%) used single self-presentation strategies which are, in descending order, 1) Justification; 2) Supplication ; 3) Excuse

The use of dual self-presentation strategies can be seen as a means of bolstering the arguments of the requests and increase the possibility of approval. Table 1 shows the self-presentation used in the data and the percentages of occurrence.

Table 1. Self-Presentation

\begin{tabular}{ll}
\hline Self-Presentation strategies & Percentage \\
\hline & \\
Supplication and exemplification & $28 \%$ \\
Justification and exemplification & $20 \%$ \\
Justification & $14 \%$ \\
Excuse and exemplification & $12 \%$ \\
Supplication & $11 \%$ \\
Excuse & $9 \%$ \\
Apology and justification & $3 \%$ \\
Justification and self-promotion & $3 \%$ \\
\hline
\end{tabular}

It is not surprising the supplication was the most used self-presentation strategy. Many of the request letters actually appealed to the pathos of the reader. In their request for readmission to the university or to their respective programs and extension of payment, the students usually talked about financial problems as their primary reason for not being able to pay on time, or not being able to continue their studies. The financial problems had been caused by multiple factors such as sickness or death in the family, delay in remittances, or inability of the family to have adequate resources for education. Another prevalent reason would be the students' health-physical and mental. They admitted suffering 
from physical ailments such as heart and neurological problems and mental conditions like depression and bipolar disorders.

EX: 4"I underloadeded twice due to some conflicts in schedule that coincided with financial problems at home. My biological father died in 2006 and it was hard for my mother to finance my education. My stepfather, on the other hand, would rather prioritize the education of my half siblings. Consequently, I started to work as a writer to support my education."

EX: 5 "Taking a leave of absence for one semester was a decision made by me and my mother. Since the start of the first semester AY 2013-2014, I had been visiting my cardiologist more frequently. My heart condition had become a burden that was difficult to ignore... My heart condition worsen and I developed insomnia. I was advised by my doctor to see a psychiatrist since he believes I might be suffering from depression. My parents and I decided that I take a break from school...."

The discourse of the letters, however, which started with supplication did not stop at highlighting weaknesses and disabilities. The succeeding part of their letters exemplified their virtues. The students showed that they value honor and commitment by stating their willingness to pay at a specified date (in cases of requests for extension of payment).

EX: 6 "I was not able to complete my enrolment on time due to unsettled accountability. I was not able to pay on time because our family is experiencing financial difficulties. I promise to pay my tuition fee on May 15, 2015.”

Others go beyond supplication by magnifying how the approval of their request would affect their ideals. In the next example, the student requested readmission from AWOL. At first, he used supplication by citing his family's hardships and his medical condition. Toward the end of his letter, however, he cited how meaningful it would be for him to be able to graduate highlighting his struggle to continue his education. The student redirected the reader's attention from his weakness to his strength-his desire to study despite financial and physical challenges. Any educator/administrator would find this request difficult to deny.

EX 7: "The best use of man's life is to strive for and obtain new knowledge that he will share and thus further the minds and lives of other men. The learning and development opportunities that are available in XX (name of the university) are invaluable, and I believe in eventually graduating not as a means for me to earn but as a stepping stone in becoming a valuable contributor to the learning and knowledge that can be found in XX. I am grateful for the opportunity to continue my education."

There were also request letters that solely used justification (14\%). A fundamental principle in theories of self is the idea that people want to view themselves positively and they want others to have the same view (Brown, 1998). Knowing how to own up to a mistake impresses upon the reader a mature, well- 
adjusted individual. Presenting oneself less favorably by admitting failure in judgment or a misbehavior, ironically, becomes favorable to the student.

Ex 8: "I admit that I always prefer not to drop subjects which I am most likely to fall short of because I would still like to continue attending these classes despite of the risk it might cause my official record. Also, I would like to state that I only lack a few requirements for my subject with INC grades which I am planning to fulfil within this semester. I understand that the efforts I exerted were still inadequate for me to have a good status in our college but I am very much hoping that you would give me another chance..."

Ex 9: "The reason why I dropped the course was because of my failure to cope with the lessons and the requirements. I was balancing work and academics last semester and it took a toll on my studies. I missed a number of classes plus I failed to submit a paper and an exam that was $40 \%$ of our grade. I had to withdraw from class with my professor's consent."

Twelve percent $(12 \%)$ of the letters used excuse with exemplification. In using these strategies, the students acknowledged their inability to pay or comply with requirements; however, they denied responsibility and instead blamed other people.

Ex 10: "I was not able to process my change of matriculation because of the late enlistment of my professor. He was able to enlist me formally in the CRS website only after the deadline of the enrollment.

EX 11: "Unfortunately, during that period, my professor in PE gave me an INC. My professor told me that the only way for me to complete the course is to attend the finals of his class.

In both letters, the professors' actions resulted in the delay of enrollment or graduation of the students. There was no mention of why the student was given an INC. In the other example, the student did not mention why the professor enlisted him late. The self-serving information (putting the blame on the professor) was placed in the preferred dimension of the communication while the negative information (the possible lapse in judgment on the part of the student) was disregarded. These students tried to save their faces by blaming others. Fortunately, these letters comprised only $9 \%$ of the total letters.

Three percent $(3 \%)$ used apology with justification. These students started their letters with an apology for something they were not able to do or fail to comply with. The apology was immediately followed by an acceptance of responsibility. Manifesting accountability is an important factor in creating positive impression and restoring/maintaining the trust of the reader.

EX12: "I sincerely apologize for the lateness of this letter and for my late payment. I am also sorry for the inconvenience this may have caused you. I will pay the tuition fee as soon as this letter is approved. 
EX13: "I would like to apologize for the delay of payment regarding my change of matriculation process. I have forgotten and missed the deadline last Monday. I have already prepared the payment and I am hoping to pay as soon as possible."

The remaining three percent (3\%) combined justification and self-promotion. After admitting responsibility for a negative behavior, some students tried to convince the reader of their competence and ability in redirecting their academic lives to overcome their delinquency. All they need would be another chance to prove themselves. To appear modest in this situation may be misinterpreted as a weakness or lack of competence. There is a need to enhance self-description to increase the possibility of the approval of requests. In the next example, the student requested an extension of his residency. Apparently, he was dismissed by his former college and was seeking admission to another college. In the course of trying to get in a new program, he was not able to enroll for three years but is now ready to go back and finish his degree.

Ex14: "I stayed with the School of Statistics from 2006 till last semester. I started taking Speech Communication subjects from 2012-2013 though I was not yet accepted. My grades have been excellent. I received a GWA of 1.56 in the first semester and 1.6 in the succeeding semester. I am hoping for your favorable action on my request."

\section{Conclusion}

This paper examined the ways students presented themselves in their letters of request to increase the possibility of approval. Majority used an indirect organizational strategy which is consistent with the Filipino style of communication that frowns upon directness. They used dominantly justification and supplication which they balanced with exemplification. These strategies created an impression of mature individuals who initially seemed frail, weak, or even delinquent but strove to be competent, diligent, and responsible.

How do all the lexico-syntactic features, organizational and self-presentation strategies relate to constructing a desired identity?

According to Schlenker (1985), self-presentation can be seen as a goaldirected activity that occurs in a social context which has an actor (the student), an audience (the reader), and the social situation (the student makes a request which will be approved by the reader who is in administration). In this transactional view, two features define the desirability of self-presentation for the individual. The self-presentation must be beneficial in the sense that the actor sees it facilitating the attainment of his goal. The self-presentation must also be believable. The findings in the study support the observation that the selfpresentation strategies used by the students helped create acceptable identities. They presented themselves as individuals who, due to varying believable circumstances, were unable to comply with university requirements/policies. The use of modality, however, marked a turning point in many of the letters. In describing past activities/situations, the students admitted their flaws and held themselves responsible for their actions. Many of the letters, however, had a second part where the students stressed their potentials and commitment. They explicitly informed the reader of what they could do if given a chance (that is, if the request would be approved). Putting the past and future in opposition 
foregrounded a time-related positive change that was happening or about to happen to the students. The completion of the positive change would be in the hands of the reader and this strategy would significantly contribute to persuading the reader to endorse or approve the requests.

\section{References}

Barron. (2008). "Contrasting requests in Inner Circle Englishes. A study in variational pragmatics". In M. Puetz, and van Aertselaer, J.N. (eds.), Developing contrastive pragmatics: Interlanguage and crosscultural perspectives. Berlin: Mouton de Gruyter, pp.355-402.

Blum-Kulka, S. \& Olshtain, E. (1984) "Requests and apologies: A cross-cultural study of speech act realisation patterns (CCSARP)". Applied Linguistics 5: 196-213.

Blum-Kulka, S., House, J., \& Kasper, G. (1989) Cross-cultural pragmatics: Requests and apologies. NJ: Ablex.

Brown, P. \& Levinson, S. (1978). "Universals in language usage: Politeness phenomena". In E. Goody (ed.), Questions and politeness. Strategies in social interaction. Cambridge: Cambridge University Press, pp. 56-289.

Brown, P. \& Levinson, S. (1987). Politeness: some universals in language use. Cambridge: Cambridge UP.

Byon, A. (2006) "The role of linguistic indirectness and honorifics in achieving linguistic politeness in Korean requests". Journal of Politeness Research 2: 247-276.

Culpeper, J. \& Haugh, M. (2014). Pragmatics and the English language. NY: Palgrave Macmillan.

Dasdalovska, N. et al. (2016). The use of request strategies by EFL Learners. Procedia-Social and Behavioral Sciences 232 55-61.

Goffman, E. (1956). The presentation of self in everyday life. Edinburgh: University of Edinburgh Social Science Research Center.

Goffman, E. (1972). Interaction ritual: Essays on face-to-face behavior. London: Penguin Press.

Hassall, T. (1999). 'Request strategies in Indonesian'. Pragmatics 9: 585-606.

Hassall, T. (2003). "Requests by Australian learners of Indonesian”. Journal of Pragmatics 35: 19031928.

Hendriks, B.C. (2002). More on Dutch English...please? Nijmegen University Press.

Jocano, F.L. (2001). Filipino worldview: Ethnography of local knowledge. PUNLAD Research House.

Jones, E \& Pittman, E. (1982). Toward a general theory of strategic selfpresentation.

J. Suls. Psychological perspectives on the self. 1, 231-262 NJ: Lawrence Erlbaum Associates.

Ogiermann, E. (2009). "Politeness and indirectness across cultures: A comparison of English, German, Polish and Russian requests". Journal of Politeness Research 5: 189-216.

Reep, D. (2003). Techinical writing. Principles, strategies, and reading. $5^{\text {th }}$ ed. NY: Longman. 
IJHS, e-ISSN 2597-4718, p-ISSN 2597-470X, Vol. 2, No. 1, September 2018, pp. 10-21

Rue, Y., \& Zhang, G. (2008) Request strategies: A comparative study in Mandarin Chinese and Korean. Amsterdam: John Benjamins Publishing Company.

Schlenker, B. (1985) The self and social life. McGraw Hill.

Scoot, M.B. \& Lyman, S.M. (1960). Accounts. American Psychological Review. $33,46-62$.

Searle, J. (1969). Speech acts - An essay in the philosophy of language. London: Cambridge University Press.

Searle, J. (1975) "Indirect speech acts". In P. Cole, and J. Morgan (eds.), Syntax and semantics 3: Speech acts. New York: Academic Press.

Shively, R. (2011). "L2 pragmatic development in study abroad: A longitudinal study of Spanish service encounters". Journal of Pragmatics 43: 1818-1835. 